\title{
University students in crisis: University dropout and professional re-selection
}

\author{
Estudo sobre universitários em crise: \\ evasão e re-escolha profissional
}

Yvette Piha LEHMAN ${ }^{1}$

\begin{abstract}
This study attempts to identify the factors that affect the professional re-selection process and its dynamics. It also tries to create a specific assistance model to attend to the population in question. We have seen a growing number of university students who in crisis abandon the field of study they have chosen. This phenomenon requires close attention to the levels of student satisfaction and the quality of the link he has with the university. Over a five year period, 180 triaged re-selection cases, covering a wide spectrum of different courses, were analyzed and attended to (individually or in group) by a Vocational Counseling Service. Our analysis allowed us to detect the lack of elaboration in the initial selection process as one of the causes that lead students to abandon their courses. There is a clear need for public vocational counseling policies and for the creation of student service centers to deal with this phenomenon.
\end{abstract}

Keywords: Career choice; Public policies; Student dropouts; Vocational guidance.

\section{Resumo}

Busca-se, neste trabalho, identificar os determinantes que interferem no processo de re-escolha profissional e sua dinâmica, e tenta-se esboçar o modelo de atendimento específico para essa população. Tem-se observado um crescente número de universitários em crise com o curso superior escolhido, o que pode culminar em seu abandono. Esse é um fenômeno atual e requer atenção em relação à satisfação e à qualidade de vínculo que o aluno tem com a universidade. Foram analisados os casos de re-escolha triados e atendidos (individualmente ou em grupo) em um serviço de orientação profissional num período de cinco anos, totalizando 180 jovens de cursos bastante distintos. Analisando as causas de desistências pelos jovens, pode-se apontar a falta de elaboração num processo de escolha inicial como um dos fatores da desistência. Há necessidade de desenvolvimento de políticas públicas em orientação profissional, como também desenvolvimento de núcleos de atendimento aos alunos que abarque essa questão.

Palavras-chave: Escolha vocacional; Evasão escolar; Orientação vocacional; Políticas públicas.

We have observed a growing number of university students in crisis with the field of study they have chosen - a phenomenon that in many cases leads then to drop out from school. This is unprecedented in Brazil's higher education history and demands close attention to the levels of

1 Universidade de São Paulo, Instituto de Psicologia, Departamento de Psicologia Social do Trabalho. Av. Professor Mello Moraes, 1721, Bloco D, 05508-030, São Paulo, SP, Brasil. E-mail: <yvettepiha@yahoo.com.br>. 
satisfaction and the quality of the link the student has with the university.

Some universities have researched the matter in order to understand and interfere in this new phenomenon (Brasil, 1997). There has also been an attempt to open internal and external transfer conditions and possibilities; the creation of sequential courses; and selection examination for the remaining openings.

In Brazil, passing a college entrance examination and entering a university was considered for many years an "initiation rite" into the adult world, guaranteeing the individual's professional and social success. Dropping out and course abandonment present new issues and point to the end of the "myth of success" that this highly valued social space offered (Lehman, 1988).

Because this is a relatively recent phenomenon, we have asked ourselves to what point the changes in market conditions and work ideologies, as well as the creation of new competencies have made students question the survival possibilities of their future professional project.

Unemployment data, news of friends' failures, and their parents' situation on the job market affect youths. In this situation, the youth either strengthens his link with his studies and with spaces that allow for social assimilation, or he falls victim to a crisis similar to a burn-out that demotivates him (Elizalde, 2001; Lehman, 2005).

Thus, dropping out could be understood as a symptom that comes from a wide range of social changes that if not dealt with could cause this phenomenon to lead to a personal crisis and not to an understanding of the world and the job market. (Lehman, 2005).

\section{Dropping out studies}

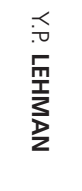

Though scarce and specific-oriented, these studies raise important issues. The first studies on dropping out and its determinants were circumscribed and dealt with courses with high levels of abandonment in order to analyze all relevant aspects.
Rabinovitch and Hamburguer (1982) studied course abandonment among physics students at the Universidade de São Paulo and established a 65\% dropout rate in the 1980s, compared to the $50 \%$ registered in 1970. According to the authors, this was the result of changes in the enrollment system that gave the students just one option.

Silva's study (1994) shows that between 1980 and 1990 there was an average 33\% dropout rate among psychology students at Universidade Estadual Paulista Júlio de Mesquita Filho of Assis (SP). The author points out problems such as: diminished interest in the course, high levels of abandonment and low motivation among professors and students for classroom activities such as issues relevant for an understanding of the phenomenon.

Maia (1984) says that the possibility of transferring from one course to another in the same university leads to an artifice known as the springboard course through which the student enrolls in an easily-accessible course to later request a transfer to the course that was his first choice. Data from the Universidade Federal da Paraíba, shows that between 1975 and 1980 undergraduate and Bachelor Degree students used this artifice (Silva, 1994).

Another phenomenon detected was the socalled disarticulated choices, that shows that because of a lack of information regarding careers and professions students enroll in courses in different areas as first and second options. This indicates that the students were merely seeking a name and were not conscious of the choices they had made.

According to Maia (1984) the main reasons target students gave for enrolling in a specific course are not linked to the activities associated to the course but to a romantic vision of the university. Silva (1994) adds that many students enroll in a university course hoping to ascend socially and sign up for any course. Course abandonment, in this case could be falsely attributed to personal reasons and run up against reality in factors connected to a macrostructure that camouflages the social questions involved in the mistaken course choice. It is important to underscore that dropping out is 
not always restricted to intra and interpersonal factors. The university many times approaches a market logic showing itself as an elitist and excluding institution.

University dropping out and the motivations behind it started being studied in specific courses with the highest dropout levels. We can cite the studies by Hamburger (1986) on the physics course; Nakamae (1991) on the nursing course; Dal Mas (1997) and Endo (1994) on the psychology course and Sandes (1992) on the social service course. These studies contain three basic kinds of analyses: motivational analysis; student profile analysis; and desistance analysis. With the exception of some particularities most of these studies arrived at the same final results. Some of these studies point out that the lack of an academic orientation policy for first year students is an important dropout factor. They also mention how the university blames the student for dropping out.

Paul and Silva (1998) speak of the lack of consideration for the socio-economic diversity of students that enter public universities. This same study describes the elitism of some fulltime day courses and the marginalization of night courses attended by students that must reconcile work with studies. These students are more prone to drop out, but not of their own accord but because of university and public policies. Veloso (2000) and Universidade Federal do Rio Grande do Sul (1991) point out that the lowest dropout levels occur in the so-called "noble courses". It is precisely these courses that are attended by students with the financial backing needed to remain in school, not needing to work to sustain themselves or others. Those who do not enjoy this kind of situation normally enroll in "non-noble" courses.

In Brazil, the impact of school evasion and desistance has always been most strongly felt in middle schools and have always been a major social concern as a result of the serious consequences they have on individuals and on the nation. But among higher education institutes, this phenomenon is a recent one that causes perplexity and a desire to want to understand it and its social and individual determinants.
This study focuses on the initial selection process, via vocational counseling, and the desistance process of higher education students who are accompanied as they select a new course. Thus, its focus is on the individual in crisis. It tries to delineate the variations that lead to the student's dissatisfaction, his dropping out, the demystifying of the dream of conquering a social space and the defining of possible substitutes.

\section{Vocational counseling and preventive action}

Until very recently vocational counseling was associated to a moment of transition between one educational cycle and another - part of an expected psychosocial crisis, of identity acquisition and of the search for autonomy despite the occurrence of affective and cognitive tensions. It had to do with what Erickson (1959) called development crisis, which for some can happen gradually while for others it occurs with abrupt changes. For Bohoslavsky (1977) PO's objective has a psychoprophylactic character. In other words a professional orientation process would be a primary prevention intervention - a health promotion factor to avoid pathogens and strengthen the individual.

Over the past two decades, with the emergence of globalization, we have witnessed the rise of a new reality in the dynamics and relations man has with work. This has defined new problems and new relations that have transformed, among other things, career, unemployment and outsourcing models. Although this new reality is still not very clearly defined, it directly or indirectly affects us. This new configuration begins introducing guidance counselors to situations of crisis and in which choices must be made. They take us back to the "accidental crisis" notion that Erickson (1959) defined as periods that are analogous to previous crisis but precipitated by vital events involving loss, the threat of loss or an increase in the supply of affective, physical and material goods.

Today, the notion of a career is more indiscriminate. It follows the "serpent model" in which horizontality (superficiality) predominates. 
Change is not always an upward movement. Many times it is just a shift in positions. Thus, in this new reality, the subject becomes responsible for his education - finding that it is a fundamental ally for his chances to grow and survive in his chosen career.

This new situation has been a reactive defense mechanism to all contexts pertaining to new work realities. Many youth see studing as a means of social insertion from the beginning of the professional selection process without considering the choice as a means to personal and social development.

Over the past few years we have seen that in this new scenario the vocational development process (Super \& Borh, 1972) suffered modifications and ruptures, forcing the individual to ask new questions regarding his choice of a profession.

Space is opened for a kind of secondary and tertiary prevention in which the crisis is already underway and intervention focuses on helping the individual to find a new organization to come out of the crisis.

The professional counselor's role is to define the variables of this problem and the kind of adaptive solutions that can be useful for the kind of prevention established. This must be done keeping in mind the strategies that deal with the positive factors that could lead to a constructive aspect of the crisis and the negative aspects that could lead to destructiveness.

\section{Method}

For this work we tried to identify the subjective, social and market factors that interfere in the re-selection process and its dynamics in order to create a specific model to attend to this population of young people.

During the re-selection process youths are confronted with the reality of a choice that failed and the elaboration of a mourning period. At this point it is necessary to discover the variables that determine the objectivization of the chosen course, the process during the first choice and its 48 consequence in the second. Also to be considered are the variables present in his current situation (course, personal and emotional life) and the reasons leading him to think of dropping out.

The choice of the assistance model began with a triage interview conducted by a psychologist. The dynamics of each student was diagnosed before we decided what kind of individual sessions were needed (an average of 10 to 12 sessions of 50 minutes each) or group sessions with 10 to 12 people (five, two-and-half hour sessions).

Individual sessions were recommended whenever personal and emotional issues prevailed over those referring to professional choice thus making it difficult to deal with in a group.

Whenever possible, professional guidance re-selection groups were formed in accordance to age and the duration of the course in which the students were enrolled. This differentiation was made after we noted that the problems surrounding selection are different at the beginning, middle and end of the course.

\section{Participants}

In this work we will take a look at the analysis made of the 1996 to 2002 triage interviews of youths that entered a Professional Guidance Service and who were diagnosed as professional reselection cases, according to Table 1 below.

During this period we had 180 youths enrolled in the Professional Guidance Service. Of this total, 85 came from state and federal universities and 95 from private institutions - of all socio-economic levels. Eighty five students went through a Professional Guidance process. Of these, 46 came from public universities while 39 were enrolled in private universities. The remaining 95 did not show up when called nor showed any interest in the service. Another factor observed was the modality of the proposed assistance. It is important to note that because of increased demand, we proposed group sessions for these cases. When called to attend an assistance modality, some showed up just once and others failed to show 
Table 1

Assistances provided by the Professional Guidance Service Institute of Psychology, Universidade de São Paulo (1996 - 2002)

\begin{tabular}{|c|c|c|c|c|c|c|}
\hline \multirow{2}{*}{ Year } & \multicolumn{2}{|c|}{ Individual assistance } & \multirow{2}{*}{ Group assistance } & \multirow{2}{*}{ Dropouts } & \multirow{2}{*}{ Referrals } & \multirow{2}{*}{ Total } \\
\hline & Concluded & Not-concluded & & & & \\
\hline 1996 & 2 & 2 & - & 6 & - & 10 \\
\hline 1997 & 7 & 1 & - & 21 & 1 & 30 \\
\hline 1998 & 12 & 2 & - & 10 & - & 24 \\
\hline 1999 & 6 & 1 & 10 & 6 & - & 23 \\
\hline 2000 & 8 & - & - & 14 & - & 22 \\
\hline 2001 & 11 & 1 & 7 & 5 & - & 24 \\
\hline 2002 & 20 & 6 & 15 & 6 & - & 47 \\
\hline Total & 66 & 13 & 32 & 68 & 1 & 180 \\
\hline
\end{tabular}

up at all. This did not happen with those who were attended to in individual sessions. As a result we were led to define the emergency state, and need for individual session variables and have them considered in the assistance proposal for dropout or re-selection cases

Seventy nine students signed up for individual sessions, 66 of whom concluded the sessions. Thirteen began but did not reach the end. Of the 68 who signed up for group sessions, 32 showed no interest when called and thus were considered dropouts.

Considering the courses analyzed, in which 85 people were assisted, none of the areas predominated over the other (human, exact or biological sciences).

We observed that close to one third of the 180 students enrolled experienced a crisis in the first semester - as soon as they entered the university. We also noticed there was a difference in terms of semesters among students from public schools (20) and those from private universities (39). Course abandonment predominates in the third semester both for public universities (22) and private schools (16). In the fifth semester, 11 students from public institutions dropped out while six were from private schools.

We saw that in 50 of the 85 individuals assisted (close to $60 \%$ ) the dropping out crisis was concentrated in the first three semesters, while among the remaining 40 percent, the crisis took place in different semesters. It is interesting to note that among public university students the tendency toward crisis and course abandonment is concentrated in odd-numbered semesters, perhaps indicating that the crisis occurs with more intensity at the start of each year.

Another hypothesis is that without the economic pressure to pay monthly tuition fees, public university students have more space for reflection and elaboration of their doubts, thus helping them make a greater effort to remain in the course.

\section{Results}

As for the motives for dropping out that are linked to the initial professional selection process, $44.62 \%$ of the youths said that when they made their choice they excluded their active participation and to a certain degree followed suggestions made by others. They tried to make a selection of accommodation. They also showed a certain detachment from responsibility for they did not seek information and did not take possession of their choice.

For these individuals, dropping out was the moment when they returned to a previous stage in order to participate in a more active and committed way in the process of deciding their future.

Of the total number of individuals attended, $30 \%$ attributed their dropping out to reasons directly related to the course:

a) Many times, their deception with the course reveals a lack of information concerning their 
initial choice, be it in relation to the chosen course or in terms like which college to attend, the differences and emphasis involved and the weight of each subject in different universities.

"There was a lot of biology in the Psychology course in Ribeirão";

"There were a lot of exact science courses".

b) Disillusionment with professors. Here, they personalize their dissatisfaction by delegating to the professor the power to stimulate their interest in the course. It is interesting to note that the professor-student relationship in the middle education context is closer and the tasks and evaluations occur in a constant and continuous fashion. This proximity disappears in the university where the relationship is more impersonal and where the work is delegated in an apparently more liberal fashion, although the evaluation is quite rigorous. This difference is only noticed after some failure has taken place. These situations of failure are unknown to many individuals who most of the time were considered excellent high school students. "The professors are not very interested"; "None of my professors were stimulating".

c) A third factor is the lack of information on the qualities and aptitudes necessary for each course. Students say that not wanting or not being able to correspond to the profile required by the course is problematic. "One has to study a lot".

d) Overall disappointment with the course: "I was disenchanted with Tourism"; "I was very disappointed with the Language and Literature Major course".

e) Disappointment with the university. "The university and the course are very weak".

Dropping out for $13.46 \%$ of the students had to do with their professionalization. In other words as they approached the profession of their choice, they felt an overall disappointment with the activities involved.

"Engineers exercise a cold profession"; "I don't see myself teaching a class".

For $10.58 \%$ of the students, their decision 50 to drop out was due to personal reasons, mainly relationship and emotional problems such as internal changes, the end of a love affair, family problems, or difficulties to assume responsibilities. These were followed by financial problems like the need to work to help the family, tuition payment and unemployment. Also mentioned were difficulties to adapt to the course and colleagues due to relationship problems and disagreements with the students' and professors' ways of thinking.

\section{Qualitative analysis}

Of the re-selection cases attended to in which course abandonment did not occur, students alleged that they did not actively participate in the selection process at the initial moment of courseselection. The youths assisted said they delegated the decision to their parents, or were influenced by them, allowing them to choose their careers or idealize the exercise of a determined profession. Also mentioned was the influence exerted by other relatives and friends. They also revealed a certain indifference with the process and the cancellation of their own will in this moment of choice.

A second factor mentioned by the students was that when making their choice they were influenced by the activity they were exercising at the time, or by a technical course they had taken in the past. This made the aspect of continuity predominate when making their choice. What predominated in this now-unsatisfactory process are the influence of a situation and the nonconsideration of the fact that a technical course represents the past, the current job to the present and the job market to the future.

A third factor emphasized was the failure to achieve another objective, another university course. Students said that by opting for a course that was similar, or of the same area rather than choosing another more "noble" course - one harder to get into - they ended up disappointed with the course or perceived that it was not worthwhile making the change. The resulting anguish made them think of dropping out.

The same argument was used when the choice was made because of the ease to enter the 
university via college entrance examinations. In this case, the chosen course is used as a springboard to get into another one. This strategy leads to disillusionment when the individual perceives that he will not be able to get into his target course through transfers or other subterfuges.

Another factor linked to the selection process is the split they made between studying and profession. In other words, the choice was made thinking only of the studies that could be made without taking into consideration the profession to be exercised. Thus, the reasons mentioned had to do with the individual's disillusionment in knowing that the profession he was to exercise was linked to that which he studied as a leisure activity or for his own cultural enhancement. Here we see the importance of the reasons attributed to the lack of information and to the lack of knowledge of the area involving the selected course. Students claim that they did not seek information, that they did not take possession of their selection and thus ended up considering dropping out.

\section{Conclusion}

In analyzing what leads youths to drop out, we see how vocational counseling provided the moment the decision is being made, could have a positive impact and help reduce dropout rates. In this respect, remember that $45 \%$ of the students mentioned their non-participation in the process of choosing a course, while another $31 \%$ said they did not know the reality of the course and profession chosen.

According to the results obtained, youths that underwent vocational counseling at a moment of crisis with their university course managed to elaborate their doubts and link themselves to their original project in a harmonious way. The data also shows that $73 \%$ of those in vocational counseling sessions clarified the reasons that led to their crisis and did not abandon their course or their study project.

This is a significant index and could highlight the importance of having a space, within an institutional context, in which the student can express and elaborate his doubts related to the selected course and to the university's ability to act on the variables that lead to a crisis. A student service center would encompass a space to elaborate the flaws that result in damaging consequences and affect both institution and student.

Some considerations could be made as to the characteristics of this service center and differentiate them from the existing service for students making their first choice. Analyzing some of the variables that affected this population, we saw that 95 people who signed up did not attend when summoned or did not show any interest in the service.

One hypothesis is that for these youths the interval between signing up in the service and its startup cannot be a long one given the urgency of the intervention. To contain the crisis these youths are experiencing and which is a major dropping out factor, the intervention must occur in a minimum amount of latency time and preferably in individual sessions.

We therefore alert that assistance in this dropping out context must, in the future, include an adequate space and contextualize an individual and rapid assistance due to the youth's anxiety situation.

Our observations that the reasons for dropping out vary according to the moment of the course were confirmed.

a) At the start of the course the problem is directly related to the fact that the student was not committed to his first choice. We also observed that during this initial period these youths face difficulties in adapting to change from a high school context to a university one.

b) Halfway through the course, in the fourth or sixth semesters, an ontological question predominates in the crises these youths face. It is when they begin to question the meaning of their activity.

c) At the end of the course, the crisis occurs after the second half in which more objective questions are asked about the occupation to be 
exercised and to ways to grow and develop in the profession.

Our data points to a specificity in professional re-selection dynamics according to the moment of the course when this takes place. There are also differences between private and public universities regarding the moment when the crisis emerges. We noted that in private universities dropping out almost never takes place at the end of the course. It mostly occurs during the first semesters.

To deal with this new problem - students in crisis - student service centers must be developed and installed in universities.

Our course abandonment data allows us to state that if an individual has the space in which he can elaborate his doubts and questions, the dropping out rate is reduced substantially.

We must emphasize that all these aspects could be instituted during the middle education years - before students enter the university system. Vocational counseling could help install, at an earlier stage, this articulation with social spaces by formulating work projects with prophylactic characteristics that could be developed in the community.

Public policies must focus on, and accompany, these aspects that underscore the importance of universities having professional and career orientation spaces that could help students in crisis.

The need to study this problem emerged when we of the Vocational Counseling Service observed the growth of this population. We began our studies in order to understand this new phenomenon, ascertaining the reasons for dropping out and determining the dynamics of a re-selection process. The data obtained over the past few years continue to confirm that dropping out levels remain low when the university offers the student the space in which he can recover the link between his project and the means to achieve it.

This study served as the base for the creation of a specific service that without any official divulgation has attracted the spontaneous interest

52 of students.
We hope that the results of this study will help universities become aware of the need for a space for students in crisis and encourage them to organize assistance services to help deal with this problem. The study highlights the positive results for the student and consequently an equally positive result for the institution.

\section{References}

Bohoslavsky, R. (1977). Orientação vocacional: a estratégia clínica. São Paulo: Martins Fontes.

Brasil. Ministério da Educação e Cultura. Comissão Especial de Estudo de Evasão. (1997). Diplomação, retenção e evasão nos cursos de graduação em Instituições de Ensino Superior Públicas. Brasília: MEC.

Dal Mas, E. T. (1997). A dúvida da continuidade dos estudos universitários: uma questão adolescente. Taubaté: Cabral.

Elizalde, J. H. (2001). Las crisis del terapeuta. In Psicoanalisis: focos y aperturas. Montevidéo: Psicolibros.

Endo, R. M. S. (1994). Evasão num curso de Psicologia: estudo em instituição particular. Reunião Anual de Psicologia, 24. Ribeirão Preto: Sociedade de Psicologia de Ribeirão Preto.

Erickson, E. M. (1959). Identity and life cycle. New York: International University Press.

Hamburguer, E. W. (1986). Levantamento preliminar da evasão na Universidade de São Paulo. São Paulo: Instituto de Física.

Lehman, Y. P. (1988). Aquisição de identidade vocacional em uma sociedade em crise dois momentos na profissão liberal (Tese de doutorado não-publicada). Programa de Pós-Graduação em Psicologia Escolar e do Desenvolvimento Humano, Universidade de São Paulo.

Lehman, Y. P. (2005). Estudo sobre a evasão universitária as mudanças de paradigma na educação e suas consequências (Dissertação de Livre Docência não-publicada). Programa de Pós-Graduação em Psicologia Social, Universidade de São Paulo.

Maia, M. F. (1984). A evasão no terceiro grau: a quem interessam as razões? (Dissertação de mestrado não-publicada). Programa de Pós-Graduação em Educação, Universidade Estadual de Campinas.

Nakamae, D. D. (1991). Evasão na Escola de Enfermagem da USP: considerações sobre o fenômeno. São Paulo: Escola de Enfermagem da USP.

Paul, J. J., \& Silva, N. V. (1998) Conhecendo o seu lugar. a auto seleção na escolha da carreira. Revista Brasileira 
de Política e Administração da Educação, 14(14), 115-130.

Rabinovitch, S. V., \& Hamburguer, E. W. (1982). A evasão de alunos do curso de física da USP. Anais do V Simposio Nacional de Ensino de Física, Belo Horizonte: Sociedade Brasileira de Física.

Sandes, J. (1992). O curso de serviço social da PUCMT: um estudo sobre a evasão de sala de aula (Dissertação de mestrado não-publicada). Programa de Pós-Graduação em Serviço Social, Pontifícia Universidade Católica de São Paulo.

Silva, N. P. (1994). Entre o ideal e o real: um estudo sobre as razões que levam alunos de uma universidade pública à intenção de abandonar o curso de psicologia. (Dissertação de mestrado não-publicada). Programa de Pós-Graduação em Psicologia da Educação, Pontifícia Universidade Católica de São Paulo.

Super, D. E., \& Borh Jr., M. J. (1972). Psicologia ocupacional. São Paulo: Atlas.

Universidade Federal do Rio Grande do Sul. (1991). Evasão dos cursos de graduação da UFRGS em 1985, 1986 e 1987. Porto Alegre: UFRGS.

Veloso, T. C. M. A. (2000). Evasão nos cursos de graduação da Universidade Federal do Mato Grosso, campus universitário de Cuiabá: um processo de exclusão. Cuiabá: UFMT.

Received on: 20/3/2012

Final version on: $18 / 4 / 2012$

Approved on: 8/5/2012 
